\title{
建築外部空間の熱放射環境が \\ ダイレクトゲインシステムの性能に及ぼす影響の数值解析 \\ NUMERICAL ANALYSIS ON THE EFFECT OF \\ THE OUTDOOR THERMAL RADIATION ENVIRONMENT \\ ON THE PERFORMANCE OF A DIRECT GAIN SYSTEM
}

河 合 英 德*, 浅 輪 貴 史 ${ }^{* *}$, 梅干野 昆 ${ }^{* * *}$

Hidenori KAWAI, Takashi ASAWA and Akira HOYANO

\begin{abstract}
This study presents a simulation method to predict the effect of the outdoor thermal radiation environment on the performance of a direct gain system. As a result of error analyses for the calculation of incident solar radiation on internal surfaces and room air temperature, the error range derived from mesh resolution is revealed. Also, the numerical experiments show that this method is applicable to the examination of the performance of a direct gain system, taking into account the effects of the position and size of trees and thermal storage mass.
\end{abstract}

Keywords : Direct gain system, Passive design, Heat transmission analysis, Outdoor and indoor spaces, Thermal radiation environment, Building heat load

ダイレクトゲインシステム，パッシブデザイン，伝熱解析，建築内外，熱放射環境，建物熱負荷

\section{1. 研究の背景と目的}

環境配慮型建築への要請の高まりを受け，快適な室内気候の形成 と省エネルギーの性能向上の両立を図る手法として，日射熱を有効 に利用するパッシブソーラーシステムが注目されている。特に日射 熱を蓄熱部位に蓄えるダイレクトゲインシステムはその最も直接的 な熱利用の形態の一つであり，冬季において有効な手法であるため 数多くの研究例がある。近年では技術開発が進み, 潜熱蓄熱材 ${ }^{1)} に$ よる蓄熱性能の向上や床暖房等の補助設備との併用 ${ }^{2)}$ 可能である。 ダイレクトゲインシステムの大面積の開口部は熱環境以外の視点 からも建築外部空間に対して開放的なデザインとしても有効である。 その反面, ダイレクトゲインシステムの性能は建物の日射熱取得に 依存することから，実際の市街地や住宅地では隣棟建物や既存の樹 木等による日射遮蔽の影響を受け, 冬季には十分な室温上昇効果が 得られないことがありうる。また，大面積の開口部を有することか ら夏季には樹木等により開口部に入射寸る日射を遮蔽するための対 策が求められる。そのため, 冬季と夏季の両時期において建築外部 空間の影響を検討できることが重要であり, それには数值シミュレ ーションによる検討が有効といえよう。

筆者らはこれまで熱的に快適な屋外生活空間の形成のために熱放 射環境の重要性に着目し，建築外部空間の熱収支シミュレーション により樹木の配置や形状, 樹種や建築外部空間の空間形態・構成材
料が熱放射環境に及ぼす影響を予測可能なツールを開発してきた ${ }^{3)}$ ダイレクトゲインシステムの性能の予測に関しても建築外部空間の 空間設計と形成される熱放射環境を考えながら，各時期の日射熱取 得と室温，熱負荷について検討できることが重要と考える。

そこで本研究では, 樹木によって形成される建築外部空間の熱放 射環境を考慮したダイレクトグインシステムの性能予測方法を示し， 樹木の配置や樹高, 落葉の有無がダイレクトゲインシステムの室温 に及ぼす影響を明らかにする。

2. 建築外部空間の熱収支シミュレーションと連係したダイレクト ゲインシステムの性能予測方法

\section{1 本研究におけるダイレクトゲインシステムの性能予測の要件}

建築外部空間の熱放射環境を考慮してダイレクトゲインシステム の設計及び性能評価を行うには，冬季の日射熱取得と夏季の日射遮 蔽を両立する視点から, 以下の要件が求められる。

1)隣棟建物や塀などの構造物の日射遮蔽の影響を考慮しながら樹木 の有効な配置や樹種を検討できること。

2)樹木や隣棟建物といった建築外部空間の構成物による日射遮蔽の

影響を考慮しながら日射熱取得のための開口部を配置できること。 3)蓄熱部位の配置, 構成材料の決定において,室内への日射の入射量 及び蓄熱部位における受熱日射量の分布を考慮できること。
* 東京丁業大学大学院 大学院生 · 修士 (丁学)

(日本学術振興会 特別研究員 DC)

** 東京工業大学 准教授・博士 (工学)

*** 放送大学 教授. 工博 (東京工業大学 連携教授)
Graduate Student, Tokyo Institute of Technology, M. Eng.

(JSPS Research Fellow DC)

Assoc. Prof., Tokyo Institute of Technology, Dr. Eng.

Prof., The Open University of Japan, Dr. Eng.

(Visiting Prof., Tokyo Institute of Technology, Dr. Eng.) 


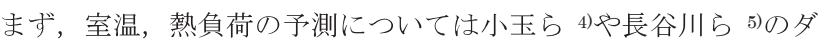
イレクトゲインシステムにおける性能予測, SMASH6) や

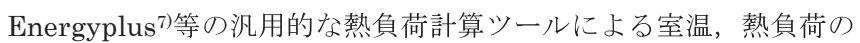
予測が挙げられる。以上の手法における建築外部空間の扱いに着目 すると, ダイレクトゲインシステムにおける性能予測については建 築外部空間の構成物や樹木による日射遮蔽によって形成される熱放 射環境が開口部の集熱性能や蓄熱部位の蓄熱性能に及ぼす影響につ いては示されていない。また, 汎用的な熱負荷計算では建築外部空 間の取り扱いに関して隣棟建物との距離や高さ等を簡易なパラメー タで扱うものと，投影図的な解析を行うものが夕られる。これらの 手法では，樹木のような複雑な形状や日射透過性を有する構成物に 関する扱いは示されていないこと, 遮蔽物の影響を考慮した日射量 を建物熱負荷計算のモデルの外表面毎に平均化して入力しているこ とから，樹木の日射遮蔽の影響を含めた室内の透過日射量の分布の 考慮が課題といえる。

一方で，樹木を含めた建築外部空間の熱放射環境を考慮した建物 熱負荷計算手法として, 樋口ら ${ }^{8)}$ が日射遮蔽の影響と長波長放射を 考慮した熱負荷計算手法を提案し, 樹木の配置, 形状, 日射透過率 の違いが建物熱負荷に及ぼす影響を示している。また，筆者らは建 築外部空間の表面温度計算を行う熱収支シミュレーション (3D-CAD 対応熱環境シミュレータ ${ }^{3)}$ ) と建物熱負荷計算の連成手 法の開発を行っている 9)。この連成手法では建築外部空間の全表面 をメッシュ分割したうえで熱収支計算に基づき, 外表面の吸収放射 量を算出し, 建物熱負荷計算の面毎の平均值を建築外表面の面毎に その平均值を境界条件として与えて熱負荷計算を行うことにより, 建築外部空間の熱放射環境を考慮した建物熱負荷を算出する。しか し，いずれの手法も蓄熱部位の配置や仕様が室温変動に及ぼす影響 を予測することは対象としておらず,室内に透過した日射の取り扱 いが課題である。

\section{2 性能予測方法のアルゴリズム}

本研究では, 樹木の配置, 樹種や開口部, 蓄熱部位の配置を検討 することから，既往の熱収支シミュレーションと建物熱負荷計算の 連成手法 9)アルゴリズムにおいて, 建築外部空間の全表面で行っ ていたメッシュ分割を室内の壁, 天井, 床（蓄熱部位を含む）の表 面についても同じ空間分解能で行い，建築外表面の日射量分布や表 面温度分布に加えて, 室内表面の直達日射量分布を算出するように 改良を行う（図 1)。室内については日射熱取得と蓄熱部位の吸収日 射量が室温, 熱負荷に及ぼす影響を予測することを目的とするため, 従来の建物熱負荷計算と同様に各室を一質点として扱う。具体的な アルゴリズムについては以後に示す。

\section{(1)建物外表面の吸収放射量と表面温度算出}

既往の熱収支シミュレーション ${ }^{3)}$ による表面温度の算出アルゴリ ズムと同様に, 3 次元の形状を再現した建物, 樹木, 屋外構造物及 び 2 次元の地表面の全表面をメッシュ分割し, 外表面の熱収支解析 を行う。熱収支解析では各メッシュの質点において建築外部空間の 表面の熱収支計算（直達日射, 天空日射, 反射日射, 大気放射, 周 辺地物との長波長放射の授受注1), 対流熱伝達, 潜熱輸送, 式(1)）上 各面断面方向の 1 次元非定常熱伝導計算を行う。本研究ではこの熱 収支解析で得た建物外表面の吸収放射量（式(2) を建物熱負荷計算 の境界条件として用いる。

$$
\begin{array}{rr}
I+R_{0}+R_{1}+Q_{H}-Q_{E}-Q_{G}=0 & \cdots \cdot \text { 式(1) } \\
q(t, m, j)=I+R_{0}+R_{1} & \cdots \cdot \text { 式(2) }
\end{array}
$$

$t:$ 建物番号, $m$ : 面番号, $j$ : 質点番号, $q(t, m, j)$ : 建物 $t$, 外壁面 $m$, 質点 $j$ に扔ける吸収放射量 $\left[\mathrm{W} / \mathrm{m}^{2}\right], I$ : 吸収日射量 $\left[\mathrm{W} / \mathrm{m}^{2}\right], R_{0}$ : 大気放射量 $\left[\mathrm{W} / \mathrm{m}^{2}\right]$, $R_{1}$ :長波長放射量 $\left[\mathrm{W} / \mathrm{m}^{2}\right], Q_{H}$ : 対流熱伝達量 $\left[\mathrm{W} / \mathrm{m}^{2}\right], Q_{E}$ : 潜熱輸送量 $\left[\mathrm{W} / \mathrm{m}^{2}\right]$, $Q_{G}:$ 伝導熱量 $\left[\mathrm{W} / \mathrm{m}^{2}\right]$

(2)室内表面の吸収日射量の算出

既往の建物外表面における熱収支計算のアルゴリズムを室内まで 拡張し, 室内表面の各メッシュの中心から太陽方向へのレイトレー シングにより室内に入射する直達日射量の分布を算出する。隣棟建 物の日射遮蔽だけでなく, 樹木の複雑な形状による日射遮蔽や樹冠 内の日射透過距離の違いも考慮可能としている。算出した直達日射 量の分布は可視化することで, 蓄熱部位の配置等について検討する こともできる (図 9 , カラー頁)。なお，直達日射の室内一の透過に ついてはガラス空面における指向透過特性を計算に組み込んでいる。

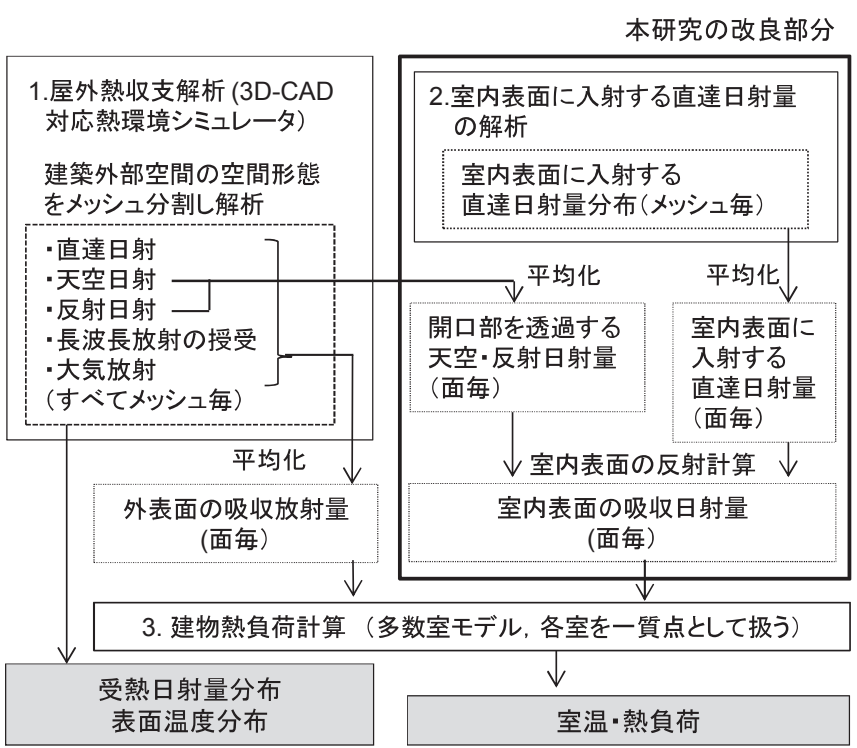

図 1 本解析のフロー

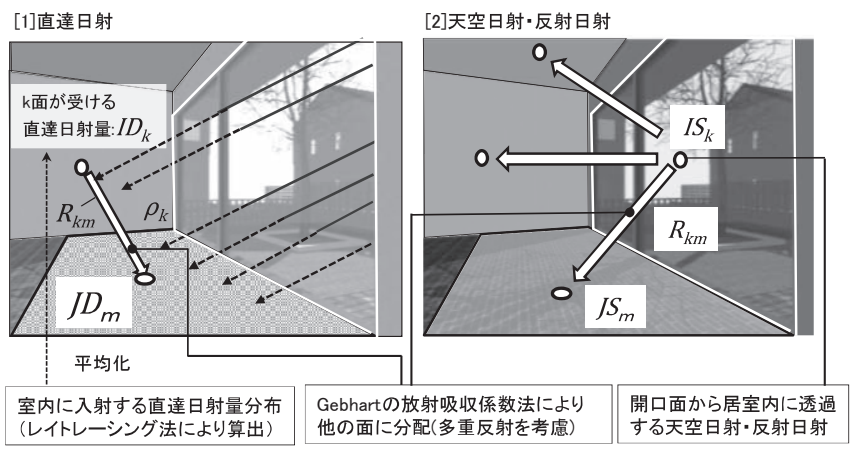

図 2 室内表面の吸収日射量の算出 
本方法では, 最終的に多数室の建物熱負荷計算において各室を一 つの質点として扱うことから, 計算負荷削減のため, 壁, 天井, 床 （蓄熱部位を含む）の直達日射量の分布は熱負荷計算の面毎に平均 化し, 一質点化する。さらに, 算出した各面毎の直達日射量は, 室 内表面を拡散面と仮定し注 ${ }^{2}$, Gebhart の放射吸収係数法（式(3) により相互の多重反射を考慮したうえで他の面に分配する（図 2, 式(4))。

$$
\begin{aligned}
& R_{i j}=\left(1-\rho_{j}\right) I D_{j}+\sum_{k=1}^{N} R_{k j} \rho_{k} I D_{k} \\
& J D_{m}=\left(1-\rho_{m}\right) I D_{m}+\sum_{k=1}^{N} R_{k m} \rho_{k} I D_{k}
\end{aligned}
$$

$J D_{m}$ : 室内表面 $m$ の吸収日射量（直達日射に由来寸る成分） $\left[\mathrm{W} / \mathrm{m}^{2}\right], I D_{m}$ : 室内に透過し $m$ 面に入射した直達日射量 $\left[\mathrm{W} / \mathrm{m}^{2}\right], R_{i j}$ 面 $i$ からの放射量のう

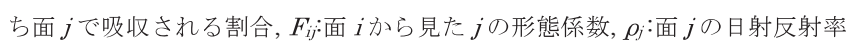

室内に透過する天空日射量については天空率が周辺建物や樹木に よって著しく減少する場合にその影響を考慮する必要があり, 直達 日射量と同様のレイトレーシング法による算出方法も想定できる。 しかし, 天空の全方向（立体角 $2 \pi ）$ へのレイトレーシングを行う 場合, 1 メッシュあたりの探䍒線の本数が増大寸ること, また室内 に透過する全日射量に占める割合が小さいことから，天空から開口 部への入射量 ( ( 1 ) で算出, 天空率を考慮) に日射透過率を乗じた 透過量を Gebhart の放射吸収係数法で他の室内表面に分配するこ ととする (図 2, 式(5)。反射日射量についても室内に透過する全日 射量に占める割合は相対的に小さいと考え, 天空日射と同様の手法 とする。

$$
J S_{m}=\sum_{k=1}^{N} R_{k m} \rho_{k} I S_{k} \quad \cdots \cdot \text { 式(5) }
$$

$J S_{m}$ : 室内表面 $m$ の吸収日射量（天空・反射日射に由来する成分） $\left[\mathrm{W} / \mathrm{m}^{2}\right]$, $I S_{k}$ : 空面 $k$ から透過した天空日射量, 反射日射量 $\left[\mathrm{W} / \mathrm{m}^{2}\right]$,

( 3 ) 室温・熱負荷の算出

(1)(2)での建物外表面の吸収放射量, 室内表面の吸収日射量の算 出結果を室温, 熱負荷計算に反映させるため, 壁体の熱伝導計算に おいて建物外表面側の境界条件については，（1）の解析で得たメッ シュごとの受熱放射量を面毎に平均化した值（式(6) を，室内側の 吸収日射量については (3)で算出した值（式(7)）を時系列で入力し て多数室熱負荷計算を行う（図 3)。壁体や屋根, 床の熱伝導につい ては 1 次元非定常熱伝導方程式を後退差分法により解く。本手法で は熱伝導を 1 次元として扱い, 蓄熱部位と床の境界における熱移動 については扱わないこととする。さらに室温・熱負荷の算出に関し ては空間毎に一つの質点を設定し, 室数の次元の連立方程式を立て て多数室計算を行う（式(8)。換気量は換気回数法により与える。ま た，ダイレクトゲインシステムを考える場合，吹抜けのある居室に 大面積の開口部を配置して 2 階からも日射を得る方法も想定できる が, 上下温度分布を考虑した計算が課題であり, 本研究では単一階 の居室を性能予測の対象とする。

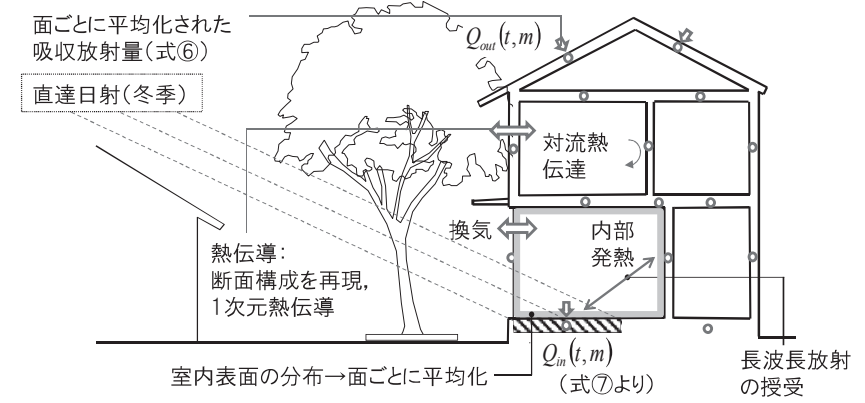

図 3 本方法における室温・熱負荷の算出

$$
\begin{aligned}
& Q_{\text {out }}(t, m)=\left(\sum_{j=1}^{L(t, m)} q(t, m, j)\right) / L(t, m) \\
& Q_{\text {in }}(t, m)=J D_{m}+J S_{m} \cdot \text { 式(6) } \\
& M r_{j} \frac{d \theta r_{j}}{d t}=\sum_{i=1}^{N_{W j}} \alpha_{c(1) i j} A_{w i j}\left(\theta_{1, i j}-\theta r_{j}\right)+C_{p \gamma} Q o_{j}\left(\theta a-\theta r_{j}\right) \\
&+\sum_{\substack{n=1 \\
n \neq j}}^{N_{r}} C_{p \gamma} Q r_{n j}\left(\theta r_{n}-\theta r_{j}\right)+L c_{j}-H_{j}
\end{aligned}
$$

$N r$ : 建物の室数、 $N_{W j}: j$ 室の室構成壁面数, $Q_{\text {out }}(t, m)$ : 建物 $t$, 外壁面 $m$ に おいて平均化された吸収放射量 $\left[\mathrm{W} / \mathrm{m}^{2}\right], Q_{i n}(t, m)$ : 建物 $t$, 室内表面 $m$ 亿お いて平均化された吸収日射量 $\left[\mathrm{W} / \mathrm{m}^{2}\right], L(t, m)$ ：建物 $t$, 外壁面 $m$ における 全質点数 $, M r_{j}: j$ 室の熱容量(空気+家具) $[\mathrm{J} / \mathrm{K}], \theta r_{j}: j$ 室の室温 $\left[{ }^{\circ} \mathrm{C}\right], \alpha_{c(1) i j}$ : $j$ 室 $i$ 壁面の 1 内側表面対流熱伝達率 [W/m2], $A_{w i j}: j$ 室 $i$ 壁の面積 $\left[\mathrm{m}^{2}\right], \theta_{1, j j}$ : $j$ 室 $i$ 壁の表面温度 $\left[{ }^{\circ} \mathrm{C}\right], C_{P Y}$ : 空気の容積比熱 $\left[\mathrm{J} / \mathrm{m}^{3} \cdot \mathrm{K}\right], Q r_{i j}: n$ 室から $j$ 室 に流入する空気量 $\left[\mathrm{m}^{3} / \mathrm{s}\right], \theta r_{n}: n$ 室の温度 $\left[{ }^{\circ} \mathrm{C}\right], Q o_{j}: j$ 室の外気流入量 $\left[\mathrm{m}^{3} / \mathrm{s}\right]$, $\theta a:$ 外気温度 $\left[{ }^{\circ} \mathrm{C}\right], L c_{j}: j$ 室の室内発熱の対流成分 $[\mathrm{W}], H_{j}: j$ 室の除去熱量 [W]

\section{3. 性能予測方法の誤差要因がダイレクトゲインシステムの室温変 動に及ぼす影響}

本研究では今回改良した部分における計算上の誤差要因を明らか にしたうえで，その室温への影響を明らかにする。本方法では，開 口部を透過し，室内表面に入射する日射量をメッシュに分割して計 算していることから, 計算精度が空間分解能に依存し, 誤差要因と して挙げられる注3)。空間分解能については, 既往の熱収支解析では 建物廻り〜街区レベルのスケールの建築外部空間の熱放射環境の予 測・評価を対象としていることから，200-500mm の空間分解能と して解析してきたが, 内壁で仕切られた室レベルのスケールの室 温・熱負荷の予測に対して，この空間分解能による誤差が解析結果 に及ぼす影響は大きいと予想される。

しかし, 室内の放射解析の空間分解能を向上させることは建築外 部空間の熱放射環境の評価における計算負荷を増大させるため, 両 者のバランスを考え, 空間分解能によって生じる誤差がダイレクト ゲインシステムの室温に及ぼす影響を予め把握することが必要であ 
る。よって, この空間形態の再現性に起因する誤差要因が室温の解 析結果に及ぼす影響を感度解析により示す。

感度解析では室の日射熱取得を左右する庇, 開口部, 蓄熱部位, 隣棟建物の再現性が解析結果に及ぼす影響が顕著であることから, それぞれの局所的な誤差が解析結果に及ぼす影響を要素別に明らか にする。さらに, 各要素の組み合わせによって生じる複合的な影響 による誤差を，空間分解能を変化させて確認する。

\section{1 解析条件}

解析対象とする建物の基本型は日本建築学会の戸建住宅の標準問 題 10)に基づき作成し（図 4)，ダイレクトゲインシステムの日射熱取 得を想定した改良点として, 居室には南に面した大面積の開口部と 蓄熱部位を配置する。居間については日射熱取得の誤差が室温に及 ぼす影響の生じやすい場合を想定し，居間の床面の南西側 4 分の 1 に蓄熱部位を配置している。蓄熱部位はコンクリートとし，その厚 さは既往研究 5)で示されている值を参考に $150 \mathrm{~mm}$ とした。建物周 辺の地表面の材料は乾燥裸地とし, 日射反射率は 0.2 と設定した (表 1)。気象条件は冬季晴天日として標準気象データ（空気調和・衛生 工学会, 空調設備基準委員会作成）の東京のデータより, 標準年 1 月 23 日のものを用いる。また, 晴天日が連続し, 蓄熱が室温変動 に与える影響が顕著な状態を仮定し, 計算は 4 日間助走計算させ, 5 日目の結果を周期定常解として採用している。内部発熱は上記の 標準問題の計算条件と同様とする。また，換気回数も上記の標準問 題の計算条件に基づき各室に終日 0.5 回/h を設定した。

\section{2 感度解析の結果}

（1）開口部, 庇, 蓄熱部位, 隣棟建物の再現性が室内の透過日射量

$$
\text { と室温に及ぼす影響 }
$$

開口部，庇，蓄熱部位については空間形態の再現性に局所的な誤 差が生じた状況として, 建物の基本型を $200 \mathrm{~mm}, 100 \mathrm{~mm}$ の空間分 解能で解析寸る計算ケース (N-200,N-100) に対して, 開口部の幅 庇の出, 蓄熱部位の設置面積が空間分解能に応じて異なる計算ケー 又 (図 5(A), (B), (C)の N-E200, E100, Win200, Win100, AC200, AC100）を設定し比較した。また，隣棟建物については比較のため 計算ケースとして隣棟がある状況を想定し, $100 \mathrm{~mm}$ と $200 \mathrm{~mm}$ で の計算を行い（図 5 (D) の $\mathrm{AD}-100, \mathrm{AD}-200$ ), その次に隣棟建物 の高さが各々の空間分解能に応じて異なる計算ケース（図 5(D)の $\mathrm{AD}-\mathrm{H} 100, \mathrm{AD}-\mathrm{H} 200)$ を設定し，比較を行った。解析対象日におい て隣棟建物の影の端が開口部上に到達するよう, 隣棟建物との距離 を南北 $8 \mathrm{~m}$, 東西 $5 \mathrm{~m}$ とし, 解析対象の建物の周囲に配置寸る。

表 2 に各誤差要因が室内の透過日射量, 蓄熱部位の吸収日射量, 室温に及ぼす影響を示す。まず $200 \mathrm{~mm}$ で計算を行った場合，基準 となる計算ケース $(\mathrm{N}-200, \mathrm{AD} 200)$ と開口部, 庇, 蓄熱部位の形 状が異なる計算ケース (N-E200, N-Win200, N-AC200, AD-H200) とを比較した際の室温差は最大で $0.4^{\circ} \mathrm{C} \sim 1.1^{\circ} \mathrm{C}$ となる同様に $100 \mathrm{~mm}$ の場合は $0.2^{\circ} \mathrm{C} \sim 0.6^{\circ} \mathrm{C}$ となる。このうち室温差への影響が 大きいものは庇と隣棟建物であり, 空間分解能 $200 \mathrm{~mm}$ における室 内に透過する直達日射量の差の最大值がそれぞれ $332 \mathrm{~W}, 452 \mathrm{~W}$ と 開口部の幅の違いに比べて相対的に大きい。この傾向は空間分解能 $100 \mathrm{~mm}$ の場合も同様である。

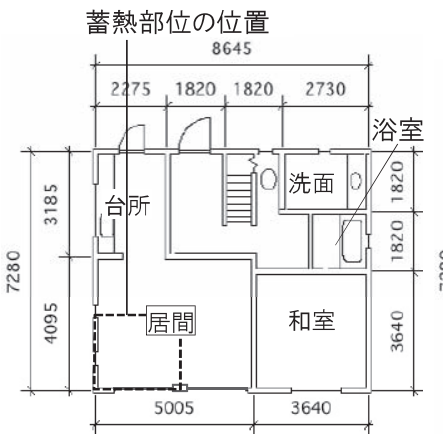

$1 \mathrm{~F}$ 平面

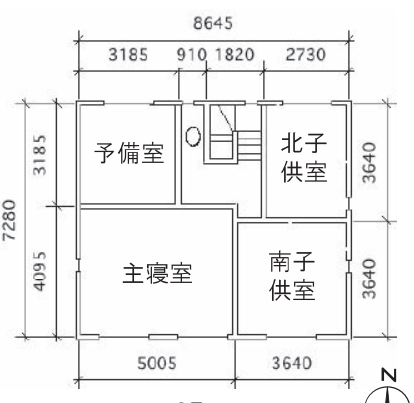

$2 \mathrm{~F}$ 平面
図 4 感度解析に用いる建物の基本型の平面図

表 1 建物および地面の断面構成と熱物性值

\begin{tabular}{|c|c|c|c|c|c|c|}
\hline 部位 & $\begin{array}{c}\text { 構成材料 } \\
\text { (室内側から) }\end{array}$ & $\begin{array}{l}\text { 熱伝導率 } \\
{[\mathrm{W} / \mathrm{m} \cdot \mathrm{K}]}\end{array}$ & $\begin{array}{c}\text { 容積比熱 } \\
{\left[\mathrm{kJ} / \mathrm{m}^{3} \cdot \mathrm{K}\right]}\end{array}$ & $\begin{array}{c}\text { 日射反射率 } \\
{[-]}\end{array}$ & $\begin{array}{c}\text { 長波長放射 } \\
\text { 率[-] }\end{array}$ & 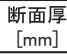 \\
\hline \multirow[t]{5}{*}{ 外壁 } & 石言ボード & 0.17 & 1030 & 0.4 & 0.95 & 12 \\
\hline & 断熱材 & 0.04 & 20 & - & - & 100 \\
\hline & 空気層 & \multicolumn{2}{|c|}{$\mathrm{R}=0.09 \mathrm{~m}^{2} \mathrm{~K} / \mathrm{W}$} & - & - & 30 \\
\hline & 合板 & 0.19 & 715 & - & - & 9 \\
\hline & モルタル & 1.51 & 1600 & 0.2 & 0.9 & 30 \\
\hline \multirow[t]{5}{*}{ 屋根 } & 石亳ボード & 0.17 & 1030 & 0.4 & 0.95 & 12 \\
\hline & 断熱材 & 0.04 & 200 & - & - & 100 \\
\hline & 空気層 & \multicolumn{2}{|c|}{$\mathrm{R}=0.09 \mathrm{~m}^{2} \mathrm{~K} / \mathrm{W}$} & - & - & 140 \\
\hline & 合板 & 0.19 & 715 & - & - & 12 \\
\hline & スレート & 1.2 & 1830 & 0.2 & 0.9 & 12 \\
\hline \multirow[t]{3}{*}{$\begin{array}{ll}\text { 開口部 } \\
\end{array}$} & 透明ガラス & 0.17 & 1910 & 0.08 & 0.94 & 3 \\
\hline & 空気層(複層ガラス) & \multicolumn{2}{|c|}{$\mathrm{R}=0.05 \mathrm{~m}^{2} \mathrm{~K} / \mathrm{W}$} & - & - & 6 \\
\hline & 透明ガラス & 0.17 & 1910 & 0.08 & 0.94 & 3 \\
\hline \multirow{4}{*}{ 蓄熱部位 } & タイル & 1.4 & 2000 & 0.2 & 0.9 & 5 \\
\hline & ヨンクリート & 1.5 & 1940 & - & - & 150 \\
\hline & ポリスチレンフォムム & 0.04 & 40 & - & - & 50 \\
\hline & \pm & 1.05 & 3340 & - & - & 400 \\
\hline \multirow[t]{5}{*}{ 1階床 } & 床板 (合板) & 0.16 & 800 & 0.4 & 0.9 & 10 \\
\hline & 合板 & 0.19 & 715 & - & - & 12 \\
\hline & 断熱材 & 0.04 & 200 & - & - & 45 \\
\hline & 空気層 & \multicolumn{2}{|c|}{$\mathrm{R}=0.09 \mathrm{~m}^{2} \mathrm{~K} / \mathrm{W}$} & - & - & 400 \\
\hline & \pm & 1.05 & 3340 & - & - & 400 \\
\hline \multirow[t]{4}{*}{ 2階床 } & カーペット & 0.07 & 171 & 0.4 & 0.9 & 60 \\
\hline & 合板 & 0.19 & 715 & - & - & 12 \\
\hline & 空気層 & \multicolumn{2}{|c|}{$\mathrm{R}=0.09 \mathrm{~m}^{2} \mathrm{~K} / \mathrm{W}$} & - & - & 45 \\
\hline & 石亳ボード & 0.17 & 1030 & 0.4 & 0.95 & 400 \\
\hline 地面 & 裸地(乾燥状態) & 1.6 & 3340 & 0.2 & 0.9 & 1000 \\
\hline
\end{tabular}

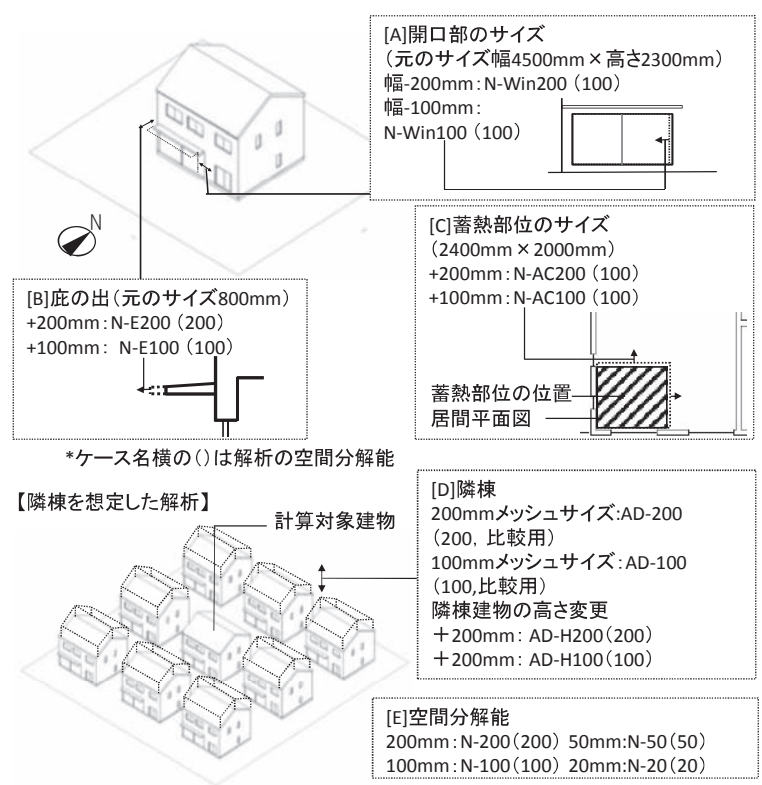

図 5 誤差要因が室内の透過日射量・室温に及ぼす影響に関 する感度解析のための計算ケース 
（2）空間分解能が室内の透過日射量と室温に及ぼす影響

図 5(E)に示寸ように, 空間分解能を $200 \mathrm{~mm}, 100 \mathrm{~mm}$ としたとき (N-200, N-100) の室内の透過日射量の計算の誤差が室温に及ぼす 影響を示すため, 空間分解能がより詳細な $50 \mathrm{~mm}, 20 \mathrm{~mm}$ の計算結 果（N-50, N-20）との比較を行う（表 2, [D]）。

$200 \mathrm{~mm}$ の空間分解能で計算した N-200 では, 室内に透過した直 達日射量は空間分解能 $20 \mathrm{~mm}$ の $\mathrm{N}-20$ に比心゙, 最大 $352 \mathrm{~W}$ 大きく, 室温は最大 $0.6^{\circ} \mathrm{C}$ 高い。一方で $100 \mathrm{~mm}$ で計算した場合には $20 \mathrm{~mm}$ で計算した場合との差の最大値は, 直達日射量が $242 \mathrm{~W}$, 室温は $0.3^{\circ} \mathrm{C}$ であった。また, 解析対象日が晴天日であり直達日射量に対寸 る天空日射量の割合が小さいこと, 建築外部空間の日射反射率が小 さいことから, 室内に透過する天空日射, 反射日射に生じる差は合 計值で直達日射量の 10 分の 1 以下となっている。

以上の感度解析より, $200 \mathrm{~mm}$ の計算では室温の結果に最大で $1^{\circ} \mathrm{C}$ 以上の影響を及ぼす場合のあることが確認できる。100mm の計算 では, それが $0.6^{\circ} \mathrm{C}$ 以内にまで抑えられるため, 以後の解析では, これをメッシュ分割に伴う誤差範囲と位置づけ, 空間分解能は $100 \mathrm{~mm}$ として計算を行うこととする。

ただし, 室の容積に対して開口部の面積が大きく空間分解能によ って生じる誤差が顕著となる場合は $100 \mathrm{~mm}$ 未満の分解能での計算 や, 直達日射計算の空間分解能を天空日射, 反射日射より細かくし, 異なる分解能で計算負荷を抑えた解析を行うことも想定される。

\section{4. 建築外部空間の樹木がダイレクトゲインシステムの室温変動に 及ぼす影響}

本性能予測方法により, 樹木の配置, 樹高, 落葉の有無の違いが ダイレクトゲインシステムの性能に及ぼす影響を分析する。ここで は, 南鉛直面からの日射熱取得量が大きく, 蓄熱部位への日射の照 射に対する樹木や隣棟建物からの日射遮蔽の影響が顕著で, 室内の 広範囲に及ぶ冬季晴天日を対象と寸る。また, 樹木の配置や樹高と, 蓄熱部位の配置の組み合わせによって蓄熱部位の受熱日射量が異な ることから, 室内の蓄熱部位の配置にパターンを設定し分析を行う。

\section{1 解析条件}

樹木を建物の南面に配置したモデルを設定し，樹木の樹高（5m， 10m）に応じて図 6 のパターン T5d, T5e，T10を作成する。T5d, T5e は室内への透過日射が樹木によって遮られる状況を想定し, 樹 高 $5 \mathrm{~m}$ の樹木を 3 本配置している。T5d については樹木の配置, 形 状による影響が顕著となる状況として常緑樹を想定したパターン, T5e は T5d と樹木の配置・形状は同一であるが冬季の日射熱取得を 考虑し, 落葉樹を想定している。 $\mathrm{T} 10$ は南側の開口部に対して冬季 の日射遮蔽の影響が少なく, 夏季にできるだけ広範囲の建築外部空 間に日射遮蔽を行うための樹木として，樹高（10m）と葉張り $(7 \mathrm{~m})$ の大きい常緑樹を想定している。なお，樹木の日射透過率は筆者ら の既往研究 9)や樋口らの研究 8)における設定を踏まえ, 常緑樹 0.1 , 落葉樹 0.8 とした。

建物の基本型については先の感度解析と同様の理由から, 日本建 築学会標準問題に基づいた計算ケースとした。ただし，室内の蓄熱 部位の配置のパターンとして図 6 の $\mathrm{A} 0$ ～A3 を設定する。A 1 は蓄 熱部位を床全面に配置しているパターンで, A2, A 3 は蓄熱部位の面 積の違いが室温変動に及ぼす影響を確認するためのパターンである。
蓄熱部位の位置の影響を確認するために, A2 は南半分への配置, A3 は西半分への配置としている。A 0 は比較用のパターンで蓄熱部 位を配置していない。

本研究では樹木の配置，樹高，落葉の有無の異なる N, T5d，T5e, T10 のそれぞれに対して，室内のパターンを組み合わせた 16 個の 計算ケースを作成し比較する。個々の計算ケースの記号は N-A1の ように示す。気象条件は冬季晴天日で，樹木による日射遮蔽が室温 変動に及ぼす影響の大きいと想定される日として, 標準気象データ

(空気調和・衛生工学会, 空調設備基準委員会作成) の東京のデー 夕より, 標準年 1 月 23 日のものを用いる。内部発熱は戸建て住宅 の標準問題 ${ }^{10)}$ に基づき設定した。また，換気回数は各室に終日 0.5 回/h を設定した。

表 2 誤差要因が室内に透過する日射量・室温に及ぼす影 響の感度解析結果

[A]庇の出, 開口部の幅の違い

\begin{tabular}{|c|c|c|c|c|c|c|}
\hline & \multicolumn{2}{|c|}{$\begin{array}{l}\text { 室内に透過する } \\
\text { 直達日射量の差 }\end{array}$} & \multicolumn{2}{|c|}{\begin{tabular}{|c|} 
室内に透過する \\
天空・反射日射量の差
\end{tabular}} & \multicolumn{2}{|l|}{ 室温の差 } \\
\hline & $\begin{array}{l}\text { 最大 }[W] \\
\text { (時刻) }\end{array}$ & $\begin{array}{l}\text { 平均 } \\
{[\mathrm{W}]}\end{array}$ & $\begin{array}{l}\text { 最大[W] } \\
\text { (時刻) }\end{array}$ & $\begin{array}{l}\text { 平均 } \\
\text { [W] }\end{array}$ & $\begin{array}{l}\text { 最大 }\left[^{\circ} \mathrm{C}\right] \\
\text { (時刻) }\end{array}$ & $\begin{array}{l}\text { 平均 } \\
{\left[{ }^{\circ} \mathrm{C}\right]}\end{array}$ \\
\hline$[\mathrm{N}-\mathrm{E} 200]-[\mathrm{N}-200]$ & $-332(13: 00)$ & 64 & $-13(11: 45)$ & 4 & $-1.1(14: 15)$ & 0.6 \\
\hline$[\mathrm{N}-\mathrm{E} 100]-[\mathrm{N}-100]$ & $-195(12: 45)$ & 37 & $-8(11: 30)$ & 2 & $-0.6(14: 30)$ & 0.3 \\
\hline$[\mathrm{N}-\mathrm{Win} 200]-[\mathrm{N}-200]$ & $-209(14: 15)$ & 47 & $-11(12: 30)$ & 3 & $-0.6(15: 15)$ & 0.4 \\
\hline$[\mathrm{N}-\mathrm{Win} 100]-[\mathrm{N}-100]$ & $-96(14: 45)$ & 15 & $-1(10: 45)$ & 0.1 & $-0.4(15: 00)$ & 0.2 \\
\hline
\end{tabular}

*平均はそれぞれの差の絶対值に対する平均值

[B]隣棟の高さの違い

\begin{tabular}{|c|c|c|c|c|c|c|}
\hline & \multicolumn{2}{|c|}{$\begin{array}{l}\text { 室内に透過する } \\
\text { 直達日射量の差 }\end{array}$} & \multicolumn{2}{|c|}{$\begin{array}{c}\text { 室内に透過する } \\
\text { 天空·反射日射量の差 }\end{array}$} & \multicolumn{2}{|l|}{ 室温の差 } \\
\hline & $\begin{array}{l}\text { 最大[W] } \\
\text { (時刻) }\end{array}$ & $\begin{array}{l}\text { 平均 } \\
\text { [W] }\end{array}$ & $\begin{array}{l}\text { 最大[W] } \\
\text { (時刻) }\end{array}$ & $\begin{array}{l}\text { 平均 } \\
\text { [W] }\end{array}$ & $\begin{array}{l}\text { 最大 }\left[{ }^{\circ} \mathrm{C}\right] \\
\text { (時刻) }\end{array}$ & $\begin{array}{l}\text { 平均 } \\
{\left[{ }^{\circ} \mathrm{C}\right]}\end{array}$ \\
\hline$[\mathrm{AD}-\mathrm{H} 200]-[\mathrm{AD}-200]$ & $-452(12: 15)$ & 48 & $-6(13: 45)$ & 0.8 & $-0.9(14: 45)$ & 0.4 \\
\hline$[\mathrm{AD}-\mathrm{H} 100]-[\mathrm{AD}-100]$ & $-308(11: 30)$ & 38 & $-3(14: 00)$ & 0.4 & $-0.6(13: 15)$ & 0.3 \\
\hline
\end{tabular}

*平均はそれぞれの差の絶対値に対する平均値

[C]蓄熱部位の大きさの違い

\begin{tabular}{l|r|r|c|c}
\hline \multirow{2}{*}{} & \multicolumn{2}{|c|}{$\begin{array}{c}\text { 蓄熱部位の } \\
\text { 吸収日射量の差 }\end{array}$} & \multicolumn{2}{|c}{ 室温の差 } \\
\cline { 2 - 5 } & $\begin{array}{c}\text { 最大 }[\mathrm{W}] \\
\text { (時刻) }\end{array}$ & $\begin{array}{c}\text { 平均 } \\
{[\mathrm{W}]}\end{array}$ & $\begin{array}{c}\left.\text { 最大 }{ }^{\circ} \mathrm{C}\right] \\
\text { (時刻) }\end{array}$ & $\begin{array}{c}\text { 平均 } \\
{[\mathrm{W}]}\end{array}$ \\
\hline$[\mathrm{N}-\mathrm{AC} 200]-[\mathrm{N}-200]$ & $230(11: 30)$ & 48 & $-0.4(14: 00)$ & 0.3 \\
{$[\mathrm{~N}-\mathrm{AC} 100]-[\mathrm{N}-100]$} & $98(11: 45)$ & 20 & $0.2(5: 45)$ & 0.1 \\
\hline
\end{tabular}

*平均はそれぞれの差の絶対值に対する平均值

[D]空間分解能の違い

\begin{tabular}{|c|c|c|c|c|c|c|}
\hline & \multicolumn{2}{|c|}{$\begin{array}{l}\text { 室内に透過する } \\
\text { 直達日射量の差 }\end{array}$} & \multicolumn{2}{|c|}{$\begin{array}{c}\text { 室内に透過する } \\
\text { 天空·反射日射量の差 }\end{array}$} & \multicolumn{2}{|l|}{ 室温の差 } \\
\hline & $\begin{array}{l}\text { 最大[W] } \\
\text { (時刻) }\end{array}$ & $\begin{array}{l}\text { 平均 } \\
\text { [W] }\end{array}$ & $\begin{array}{l}\text { 最大 }[W] \\
\text { (時刻) }\end{array}$ & $\begin{array}{l}\text { 平均 } \\
\text { [W] }\end{array}$ & $\begin{array}{l}\left.\text { 最大 }{ }^{\circ} \mathrm{C}\right] \\
\text { (時刻) }\end{array}$ & $\begin{array}{l}\text { 平均 } \\
{\left[{ }^{\circ} \mathrm{C}\right]}\end{array}$ \\
\hline$[\mathrm{N}-200]-[\mathrm{N}-20]$ & $-352(13: 45)$ & 49 & $-21(11: 45)$ & 6 & $-0.6(16: 15)$ & 0.3 \\
\hline$[\mathrm{N}-100]-[\mathrm{N}-20]$ & $-242(12: 00)$ & 31 & $-7(11: 45)$ & 2 & $-0.3(10: 15)$ & 0.1 \\
\hline$[\mathrm{N}-50]-[\mathrm{N}-20]$ & $-136(12: 30)$ & 16 & $-4(11: 45)$ & 1 & $-0.1(12: 45)$ & 0.01 \\
\hline
\end{tabular}

*平均はそれぞれの差の絶対值に対する平均值 

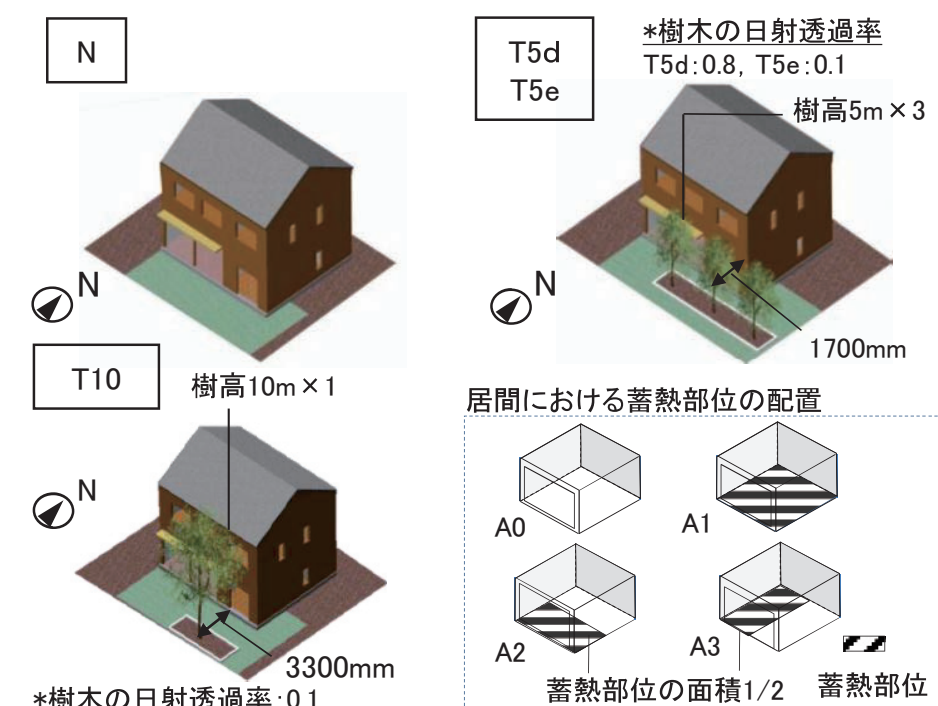

居間における蓄熱部位の配置

*樹木の日射透過率: 0.1

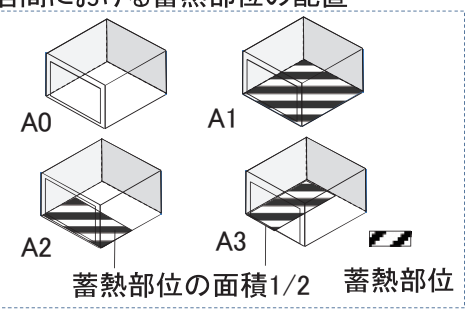

表3 各計算ケースと建築外部空間のパターン, 室内の蓄熱部位の配置パターンの対応関係

\begin{tabular}{|c|c|c|}
\hline $\begin{array}{l}\text { 計算ケース } \\
\text { 名 }\end{array}$ & $\begin{array}{c}\text { 建築外部空間の } \\
\text { パターン }\end{array}$ & $\begin{array}{c}\text { 室内の蓄熱部位の配置 } \\
\text { パターン }\end{array}$ \\
\hline $\begin{array}{l}\mathrm{N}-\mathrm{A} 0 \\
\mathrm{~N}-\mathrm{A} 1 \\
\mathrm{~N}-\mathrm{A} 2 \\
\mathrm{~N}-\mathrm{A} 3 \\
\end{array}$ & $\mathrm{~N}$ (樹木無) & $\begin{array}{c}\text { A0(蓄熱部位無) } \\
\text { A1 (蓄熱部位床全面) } \\
\text { A2 (蓄熱部位南半分) } \\
\text { A3 (蓄熱部位西半分) }\end{array}$ \\
\hline $\begin{array}{l}T 5 d-A 0 \\
T 5 d-A 1 \\
T 5 d-A 2 \\
T 5 d-A 3 \\
\end{array}$ & $\begin{array}{l}\text { T5d(樹高 } 5 \mathrm{~m} \text { の樹木 } 3 \\
\text { 本, 日射透過率0.8) }\end{array}$ & $\begin{array}{c}\text { A0(蓄熱部位無) } \\
\text { A1 (蓄熱部位床全面) } \\
\text { A2 (蓄熱部位南半分) } \\
\text { A3(蓄熱部位西半分) }\end{array}$ \\
\hline $\begin{array}{l}\text { T5e-A0 } \\
\text { T5e-A1 } \\
\text { T5e-A2 } \\
\text { T5e-A3 } \\
\end{array}$ & $\begin{array}{l}\mathrm{T} 5 \mathrm{e} \text { (樹高 } 5 \mathrm{~m} \text { の樹木 } 3 \\
\text { 本, 日射透過率 } 0.1 \text { ) }\end{array}$ & $\begin{array}{c}\text { A0（蓄熱部位無） } \\
\text { A1 (蓄熱部位床全面) } \\
\text { A2 (蓄熱部位南半分) } \\
\text { A3(蓄熱部位西半分) }\end{array}$ \\
\hline $\begin{array}{l}\text { T10-A0 } \\
\text { T10-A1 } \\
\text { T10-A2 } \\
\text { T10-A3 }\end{array}$ & $\begin{array}{l}T 10 \text { (樹高 } 10 \mathrm{~m} \text { の樹木 } \\
\text { 1本, 日射透過率0.1) }\end{array}$ & $\begin{array}{c}\text { A0(蓄熱部位無) } \\
\text { A1 (蓄熱部位床全面) } \\
\text { A2 (蓄熱部位南半分) } \\
\text { A3(蓄熱部位西半分) }\end{array}$ \\
\hline
\end{tabular}

図6建築外部空間と室内の蓄熱部位の配置の組み合わせによる 計算ケース

\begin{tabular}{l}
\hline $\mathrm{N}-\mathrm{A} 1$ \\
室内に透過する \\
直達日射量 \\
10 時: $3330 \mathrm{~W}$ \\
日積算値 : $89.7 \mathrm{MJ} / \mathrm{day}$ \\
室内に透過する \\
天空・反射日射量 \\
10 時 : $401 \mathrm{~W}$ \\
日秥算值 : $11.9 \mathrm{MJ} / \mathrm{day}$
\end{tabular}

\begin{tabular}{l}
\hline T5e-A1 \\
室内に透過する \\
直達日射量 \\
10時 : $1980 \mathrm{~W}$ \\
日積算値 : $66.7 \mathrm{MJ} /$ day \\
\\
室内に透過する天空・ \\
反射日射量 \\
10時 : $370 \mathrm{~W}$ \\
日積算值 : $8.7 \mathrm{MJ} /$ day
\end{tabular}

$\mathrm{T} 5 \mathrm{~d}-\mathrm{A} 1$

室内に透過する直達日 射量

10時 : $2980 \mathrm{~W}$

日積算值 : $83.5 \mathrm{MJ} / \mathrm{day}$ 室内に透過寸る天空 ·

反射日射量
10 時: $360 \mathrm{~W}$

日積算值 : $10.5 \mathrm{MJ} / \mathrm{day}$

$$
\begin{aligned}
& \hline \text { T10-A1 } \\
& \text { 室内に透過する } \\
& \text { 直達日射量 } \\
& 10 \text { 時: } 3000 \mathrm{~W} \\
& \text { 日積算値 } 86.8 \mathrm{MJ} / \text { day } \\
& \\
& \text { 室内に透過する天空. } \\
& \text { 反射日射量 } \\
& 10 \text { 時 }: 341 \mathrm{~W} \\
& \text { 日積算値 : } 0.2 \mathrm{MJ} / \mathrm{day}
\end{aligned}
$$
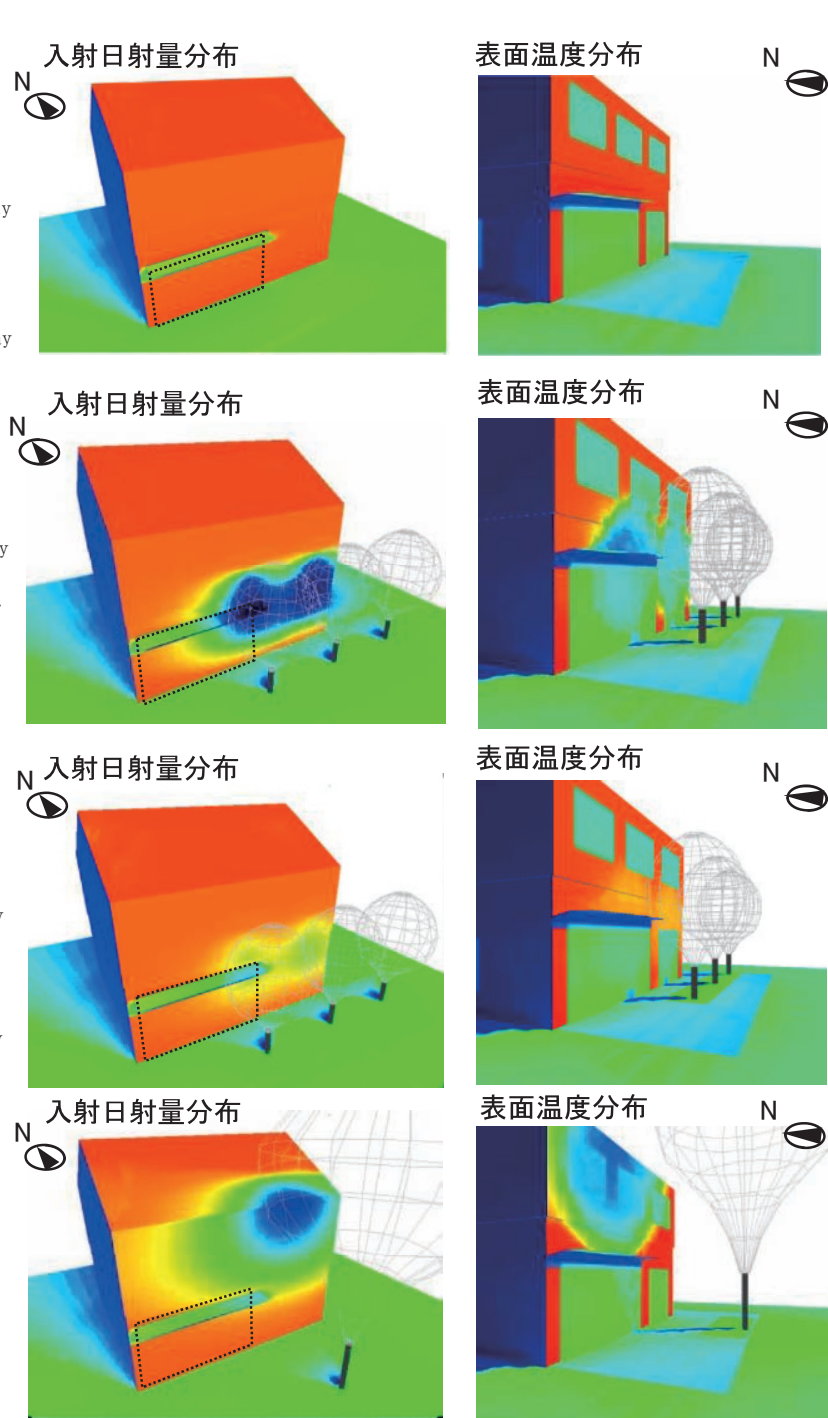

入射日射量
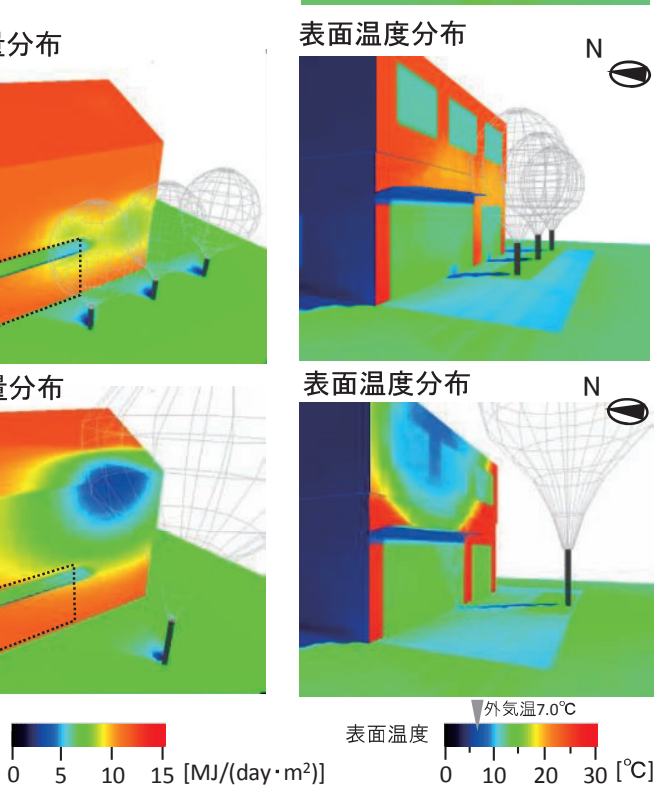

$\begin{array}{llll}0 & 10 & 20 & 30\end{array}\left[^{\circ} \mathrm{C}\right]$

図7 各計算ケースにおける外表面の日積算入射日射量と 冬季晴天日 10 時の表面温度分布

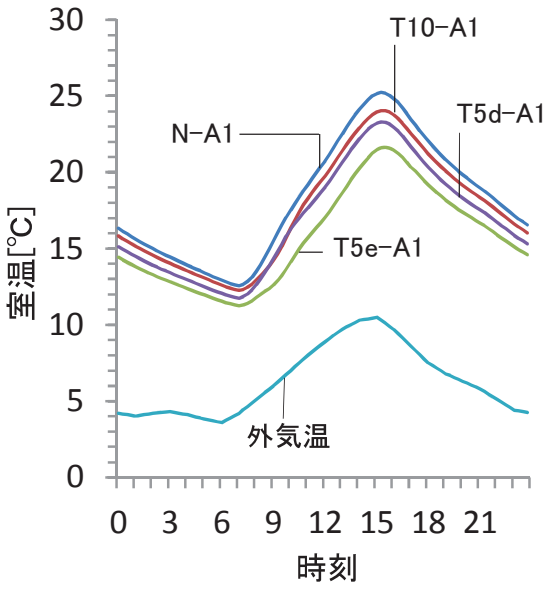

図8 建築外部空間の樹木が室温の 変動に及ぼす影響
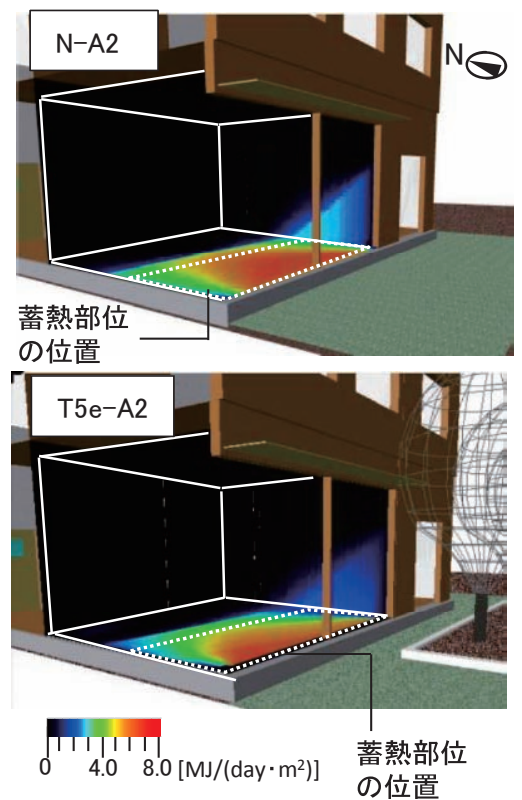

図9 室内に入射する直達日射量の 日積算值分布（冬季晴天日） 


\section{2 樹木による日射遮蔽が室温に及ぼす影響の解析結果}

樹木の配置, 樹高, 日射透過率の違いが室温変動に及ぼす影響を 示す。図 7 は N-A1, T5d-A1, T5e-A1, T10-A1 の表面温度分布と 外表面に扮ける入射日射量分布（日積算值）を，図 8 は各計算ケー スの室温変動を示している。

まず，建物外表面の受熱日射量分布と表面温度分布に及ぼす影響 に着目すると, 樹高 $5 \mathrm{~m}$ の常緑樹が 3 本ある T5e-A1 は日射遮蔽の 影響を午前中に受け, 10 時にはその影響が南側壁面の約半分に及び, 外壁の表面温度は最も低い場所で気温と同等になっている。一方で, 落葉樹を想定し, 日射透過率を 0.8 とした T5d では, 南側壁面の 10 時の表面温度は日射遮蔽の影響が最も顕著な外壁表面においても気 温より $15^{\circ} \mathrm{C}$ 高い。また, 樹高が $10 \mathrm{~m}$ あり, 樹冠下高さを高くした T10-A1 では, 日射遮蔽の影響が 2 階の南側壁面と屋根の広範囲に 及び, 10 時の表面温度は日射遮蔽の影響が最も表れている建物西側 上部で，気温相当となっている。

次に樹木の配置, 樹高, 日射透過率の違いによる居間の日射熱取 得の違いが室温に及ぼす影響に着目すると, T5e-A1 は常緑樹の日 射遮蔽により居間の開口部の東側半分で日射遮蔽の影響が顕著であ るが，樹木のない N-A1 に比べて開口部の日射熱取得の減少は日積 算で $23 \%$ ありり, 室温は最大で $4{ }^{\circ} \mathrm{C}$ 低下している。一方で，室温が 最小となる朝 7 時に着目すると, T5e-A1, T5e-A2, T5e-A3 では常緑 樹の日射遮蔽により, 樹木のない場合に比べ室温は $1^{\circ} \mathrm{C}$ 低い。また, 蓄熱部位の配置のない $\mathrm{T} 5 \mathrm{e}-\mathrm{A} 0$ と比べて $2 \sim 3^{\circ} \mathrm{C}$ 高い。樹木の日射透 過率の高い T5d-A1 や樹冠下高さの高い T10-A1 では, N-A1 に比心 てそれぞれ開口部の日射熱取得は日積算で $4 \%, 8 \%$ の減少にとどま

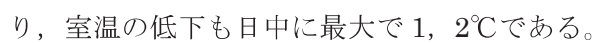

\section{3 蓄熱部位の配置・面積が室温に及ぼす影響の解析結果}

図 9 は樹木のない N-A2 と樹高 $5 \mathrm{~m}$ の常緑樹を配置した T5e-A2 における室内表面に入射する直達日射量の分布である。図 10 は各 計算ケースの室温の最小值, 平均值, 最大值と蓄熱部位の吸収日射 量（日積算值）の関係を示している。

まず，室内へ入射する直達日射の分布に着目すると，図 9 に示すよ うに N-A2 に入射する直達日射量は床の南側の中央部において 6 $\mathrm{MJ} /\left(\mathrm{day} \cdot \mathrm{m}^{2}\right)$ 以上となる。その結果, N-A2 は N-A1 に比べて蓄熱 部位の面積が半分であるが, その吸収日射量の日積算值は居間の日 射熱取得の $45 \%$ で, 床全面に蓄熱部位を配置した N-A1の $78 \%$ とな る。一方で樹木が配置された T5e-A2 の直達日射の入射量の分布に 着目すると, 床に入射する直達日射量が東半分で最大 1.7 $\mathrm{MJ} /\left(\right.$ day $\left.\cdot \mathrm{m}^{2}\right)$ 減少し, 図 10 に示寸 $\mathrm{T} 5 \mathrm{e}-\mathrm{A} 2$ の蓄熱部位の吸収日射 量は N-A2 に比べ $19 \%$ 減少している。

以上を踏まえ, 蓄熱部位の面積が室温変動に及ぼす影響に着目す ると, 床全面に蓄熱部位を配置した N-A1 は, 蓄熱部位を配置して いない $\mathrm{N}-\mathrm{A} 0$ に比べ室温の変動幅が $11^{\circ} \mathrm{C}$ 小さい(図 10)。 $\mathrm{N}-\mathrm{A} 2$ は蓄 熱部位を床全面に配置した N-A1 に比べて蓄熱部位の面積が半分で あるが, 日射の当たりやすい南半分の配置であることから室温の変 動が抑制され, N-A0 と比べた室温の変動幅の差は $8^{\circ} \mathrm{C}$ とる。この 傾向は樹木が配置された場合でも同様であり, T5e-A1, T5e-A2 の 室温の変動幅は, 蓄熱部位を配置していない $\mathrm{T} 5 \mathrm{e}-\mathrm{A} 0$ に比べ室温の 変動幅が $7 \sim 9^{\circ} \mathrm{C}$ 小さい。

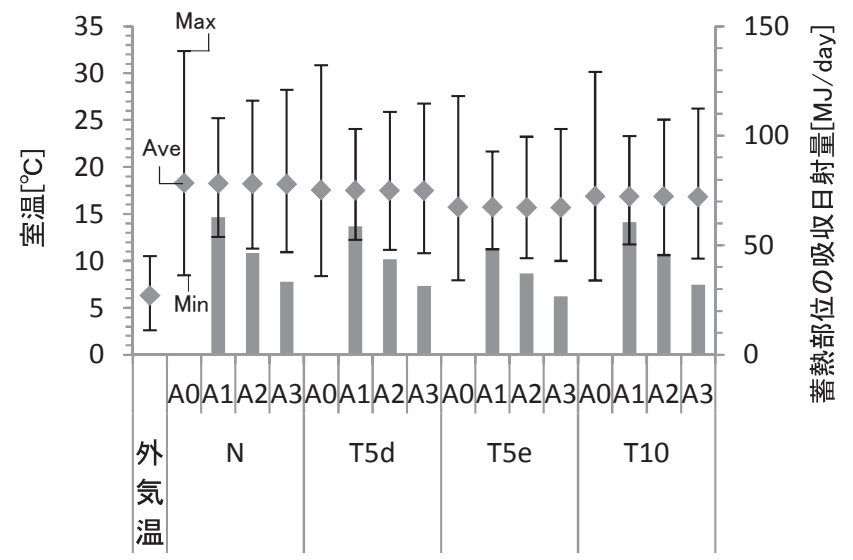

図 10 各計算ケースにおける室温の最大, 平均, 最小値, 蓄熱部位の吸収日射量（日積算値）

次に, 蓄熱部位の配置の違いが室温変動に及ぼす影響に着目する と, 西半分に蓄熱部位がある N-A3 と南半分に蓄熱部位のある $\mathrm{N}-\mathrm{A} 2$ の 2 つの計算ケースにおける蓄熱部位の吸収日射量の差は $16 \mathrm{MJ} /$ day であり, N-A3 の室温の変動幅は N-A2 に比べて $2^{\circ} \mathrm{C}$ 大き い。それに対し，樹木が配置された T5e の場合，室内の東側の床面 が日射遮蔽され, 蓄熱部位の配置 $\mathrm{A} 2$ と $\mathrm{A} 3$ の吸収日射量の差が $10 \mathrm{MJ} /$ day と減少する。樹木のない場合に比べて吸収日射量が小さ くなったことで, T5e-A2 と T5e-A3 における室温の変動幅の差もよ り小さくなり， $1^{\circ} \mathrm{C}$ となる。以上から，樹木と蓄熱部位の配置の違 い及び，その組み合わせによる室温への影響がメッシュ分割による 誤差範囲より大きいことがわかり，本手法によってダイレクトゲイ ンシステムの性能の検討が可能なことが示された。

\section{5. 結論}

既往の建築外部空間における熱収支シミュレーションと建物熱負 荷計算との連成手法において, 室内への透過日射の取り扱いを改良 することにより，樹木によって形成される建築外部空間の熱放射環 境を考虑したダイレクトゲインシステムの性能予測方法を示した。

また，本性能予測方法において，改良を行った室内表面に入射寸 る直達日射量の解析に含まれる空間分解能に起因寸る誤差要因を示 し, $0.6{ }^{\circ} \mathrm{C}$ を空間分解能 $100 \mathrm{~mm}$ のメッシュ分割における誤差範囲と して位置づけた。さらに, 本性能予測方法の有効性を示すために, 樹高, 配置, 落葉の有無の異なる樹木によって形成される熱放射環 境が冬季のダイレクトゲインシステムの性能に及ぼす影響として以 下の結果を得た。

・ 樹木の樹高, 配置, 落葉の有無の異なる計算ケースにおいて日 射熱取得が室温に及ぼす影響を解析した結果, 樹木の日射遮蔽 による室温への影響は $1 \sim 4^{\circ} \mathrm{C}$ となった。樹木の樹高が高い常緑 樹を想定した計算ケースでは, 日射遮蔽の影響が 2 階から屋根 までの広範囲に及び, 表面温度が気温相当となる部分も見られ るが，落葉樹を想定した計算ケースでは表面温度への日射遮蔽 の影響は小さい。

開口部の南側に樹高の低い常緑樹が配置された状況において蓄 熱部位を配置した場合，室内の日射熱取得量の減少による居間 
の室温の低下は最大で $4^{\circ} \mathrm{C} て ゙ あ り ，$ 朝方における室温の低下は

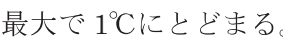

・ 蓄熱部位を日射の照射位置に応じて南半分に配置することで, 居間の室温変動幅は蓄熱部位を全面に配置した場合に比べて $3{ }^{\circ} \mathrm{C}$ の増加にとどまる。これは蓄熱部位を配置しない場合に比べ て 7 9 ${ }^{\circ} \mathrm{C}$ 小さい。

・室内に入射する直達日射量の分布を踏まえ，蓄熱部位を南半分 に配置した場合，西半分に配置した場合に比べていずれの樹木 のパターンでも蓄熱部位の吸収日射量が増加し, 室温の変動幅 が $1 \sim 2^{\circ} \mathrm{C}$ 小さくなった。

以上のように，本方法によって，樹木の日射遮蔽を受ける状況で の蓄熱部位の配置がダイレクトゲインシステムの性能に及ぼす影響 を検討できることを示した。

今後は冬季とともに夏季の日射熱取得と室温に及ぼす影響につい ても検討し, 夏季と冬季の両方に適した樹木配置と形状を明らかに する。また，建物に関しては吹抜を有する居室でのダイレクトゲイ ンの性能予測を行うため, 上下温度分布を考慮した室温の予測モデ ルや, 潜熱蓄熱材や床暖房に対応した伝熱モデルを適用し, 本方法 の適用範囲を広げていく予定である。

\section{謝辞}

本研究は日本学術振興会特別研究員奨励費（課題番号 $24 \cdot 9196 ）$ の支援を受けた。また, 本研究の一部は馮新淇君（当時, 東京工業 大学大学院生）の修士論文の一環として実施した。ここに記して謝 意を表する。

\section{参考文献}

1）例えば，近藤武士，射場本忠彦ほか：潜熱蓄熱壁体による躯体蓄熱システ ムに関する研究 潜熱蓄熱ボードの性能把握および適用効果の検討, 日本 建築学会計画系論文集, No.540, pp.23-29， 2001.2

2）金秀耿, 河野良坪, 佐藤誠, 金田一清香, 赤嶺嘉彦, 前真之, 坂本雄三 : 日射ダイレクトゲインとヒートポンプを利用した蓄熱式床暖房システム の省エネルギー性能, 第 1 報 実験システムの紹介と取得日射量の検証, 日本建築学会環境系論文集, No660, pp.169-176, 2011.2

3）梅干野昆, 浅輪貴史, 中大窪千晶：3D-CAD と屋外熱環境シミュレーショ ンを一体化した環境設計ツール 日本建築学会技術報告集 第 20 号, pp.195-198, 2004.12

4）小玉祐一郎，武政孝治：設計支援を目的としたパッシブソーラーシステ ム予測技法, 日本建築学会計画系論文報告集, No.374, pp.44-53, 1987.4

5）長谷川房雄, 吉野博, 石川善美, 松本博 : パッシブソーラーシステムの直 接熱取得方式に扔ける各種要因の数值シミュレーションによる分析一気候 条件および断熱, 集熱, 蓄熱条件の冬期の室温への影響一, 日本建築学会 計画系論文報告集, No.383, pp.8-14, 1988.1

6）例えば, 坂本雄三, 暖冷房消費エネルギー評価プログラム・SMASH, IBEC, No49 pp.25-29

7) US Department of Energy : Energy Plus Engineering reference http://apps1.eere.energy.gov/buildings/energyplus/pdfs/engineeringrefe engin.pdf, 2013.1.31 参照

8）樋口佳樹, 宇田川光弘, 佐藤誠, 木村建一: 建築屋外における日射と長波 長計算のモデルー周囲環境を考慮した住宅の熱負荷シミュレーションに関 する研究 その 1一, 日本建築学会環境系論文集 No.544,pp. 9-15 2001.6

9）浅輪貴史，梅干野昆：屋外の空間形態と構成材料を考慮した建築伝熱シミ ュレーションモデルの開発 日本建築学会環境系論文集 第 578 号, pp.47-54, 2004.4

10)宇田川光弘：標準問題の提案 住宅用標準問題 日本建築学会環境工学委 員会熱分科会第 15 回熱シンポジウム資料,pp.23-33,1985.9

11)中大窪千晶, 梅干野昆, 浅輪貴史, 深澤英之 : 屋外熱収支シミュレーショ ンにおける建築材料の日射特性を考慮した放射伝熱計算モデルの導入，日
本建築学会環境系論文集, Vol.73, No.625 pp. 275-282, 2008.3 12)一ノ瀬雅之，石野久爾ほか：指向特性を考虑した放射伝熱計算法, IBPSA-Japan 講演論文集，2005

注

注 1）建築外部空間の熱放射解析については直達, 天空, 反射日射はレイトレ 一ス法により算出し，反射日射については鏡面・拡散成分とも 1 次反 射まで考慮している。長波長放射については(1)建物などの周辺地物の 表面温度を気温同等とみなして第 1 次の熱収支計算を行い，表面温度 の近似值の時系列変化を得る(2)得られた表面温度の近似值を利用し, 各メッシュから周辺に向け探査線を射出し, 到達地点の表面温度值を 取得し，周辺メッシュからの長波長放射の時系列変化を得る。

注 2）建築材料の日射反射の指向性については中大窪ら ${ }^{11)}$ ，一ノ瀬ら ${ }^{12)}$ の実 測によって物性が確認されているが現状では建築材料の日射反射の指 向性に関する情報については十分に整備されていない。床面での反射 日射を想定すると反射日射の照射面において，反射面での入射角，鏡 面反射率，形態係数分が乗じられること，本計算ではその照射量が熱 負荷計算の面で平均化されること, 鏡面反射の照射時間が一時的であ ることを想定すれば，室温変動への影響は小さいと考える。

注 3）他にも既往手法 ${ }^{3)}$,9) との相違として，室内表面に入射寸る直達日射の探 査の始点が異なる（既往手法：外壁等の外表面, 本手法 : 床等の室内 表面）であり各室の日射熱取得の值に差が生じることが挙げられる。 この差を解消するためには本手法で算出した日射熱取得を外表面の受 熱日射量に基づき算出された日射熱取得量（既往手法）で補正するこ とも考えられる。補正を行った場合, 室温の最大值について空間分解 能 $200 \mathrm{~mm}$ で $0.3^{\circ} \mathrm{C}, 100 \mathrm{~mm}$ で $0.1^{\circ} \mathrm{C}$ 程度, 最小值については空間分解 能 $200 \mathrm{~mm}, 100 \mathrm{~mm}$ いずれの場合でも $0.1^{\circ} \mathrm{C}$ 未満の差が生じることを確 認している。本研究では室温に与える影響は小さいとし, 補正しない 值で解析を行う。

（2013年 4 月10日原稿受理，2013年 7 月29日採用決定） 